\title{
Logged In And Connected? A Quantitative Analysis Of Online Course Use And Alumni Giving
}

Andrew Tiger, Ph.D., Union University, USA

Landon Preston, MBA, Union University, USA

\begin{abstract}
Business and education stand out as two of the most prominent sectors affected by the rapid expansion of the Internet. A significant body of literature within business has been devoted to developing positive e-commerce exchanges that develop customer loyalty. While online education grows each year, the long-term significance of online education to develop a loyal alumni base has yet to be studied. Findings in marketing research literature on trust and loyalty provide exceptional significance for online education, especially in a tight economic climate that has forced colleges and universities to rely on alumni giving for operational support. This study examines the significance of online course use as a predictive variable for alumni giving at one medium sized, private liberal arts university using 3,450 students. The results show a negative correlation between the online classes and alumni giving, among other predictive variables used in alumni giving. The findings provide foundational insights for education administrators and fundraisers involved in online education and its effect on alumni giving.
\end{abstract}

Keywords: Customer Loyalty; Satisfaction; Online Education; Alumni Giving

\section{INTRODUCTION}

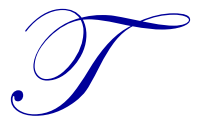

he Internet forever changes the way the world operates. Individuals, companies, and organizations around the world can communicate in just seconds, affecting the nature of industries world-wide. Business and education stand out as two of the most prominent sectors affected by this change. In particular, businesses all around the world are finding ways to enhance the customer experience through ecommerce and new mediums of communication made possible through the Internet. In education, the expansion of online course and program offerings grows at a swifter pace every year. A significant body of literature within business has been devoted to developing positive e-commerce exchanges that develop a loyal customer base. Findings in the marketing research literature provide exceptional significance for online education. The potential significance for the expansion of online degree programs and courses is great. However, the long-term significance of these programs on student satisfaction as expressed through alumni giving has yet to be studied. This paper examines the significance of online course use as a predictive variable in the undergraduate student experience as expressed through alumni giving.

\section{GROWTH AND ADVANTAGES OF ONLINE APPLICATIONS IN BUSINESS AND EDUCATION}

Within business, e-commerce has become one of the fastest growing fields for businesses due to the ability to lower overhead costs as well as gain new access to geographically dispersed markets, low cost in information exchange, and low transactional and marketing costs (Dubelaar, Sohal, and Savik, 2004; Flossi, Fraccastorro, and Moss, 2010). In addition to these benefits, companies seek to reduce their bottom lines, become more environmentally conscious, and give more flexibility to their employees through the use of telecommuting and webbased teams (Colfax, Santos, and Diego, 2008; Nydegger and Nydegger, 2010). Many of the world's leading global companies have cited substantial cost savings as the result of the increased use of technology. In 2005, Hewlett 
Packard cut costs edging \$25 billion, and Sun Microsystems saved \$71 million in real estate and nearly \$3 million in electricity savings due to the use of virtual teams and virtual offices in place of in-person meetings and traditional physical offices (Jones, Oyund, and Pace, 2005).

An added social dimension of virtual teams is employee flexibility in balancing their work and family lives. Because many workers may be confined to their house to conduct business, the standard difficulty of balancing work and life becomes an issue. However, virtual teams have overcome standard 8-5 workloads and conflicts that may occur with family time. In fact, a study conducted by Brigham Young University explored this phenomenon of telework and its benefits within IBM. In commenting of this study, the Wall Street Journal reports, "In a startling finding, researchers discovered telecommuters on flextime schedules can cram in 19 more hours of work a week, compared with people who work entirely in the office, before they begin to report work-family conflict" (Shellenbarger, 2010). As a result of technology, organizations who desire to engage in plans more conscious of the environment, enhance employee satisfaction, and socially benefit society have found a solution through the Internet.

Yet, employees are not the only individuals satisfied with the increased use of technology in commerce. Floh and Treblmeier (2006) demonstrate the significance of the relationship between loyalty and satisfaction of online customers within banking. Their study confirms that loyalty among e-banking customers directly correlates with satisfaction and trust in an online bank, as determined by web site quality and service quality. Their study also linked customer satisfaction with the overall profitability of the firm. These findings were affirmed in the work of Huang, Cheng, and Farn (2007) who noted the significance of customer satisfaction, service quality, and switching costs as significant factors for online firms to develop customer loyalty. Their study also noted the relationship of customer loyalty and the overall profitability of the firm. In fact, Floh and Treblmeier (2006) noted the enormous success of Amazon.com. Amazon boasts of sales in excess of $\$ 48$ billion in 2011 while claiming $66 \%$ of its annual sales come from returning customers (Survey: E-Commerce, 2000). These statistics affirm previous findings on the significance of customer service, website quality, and customer loyalty to building a successful online firm.

In contrast, a 2002 Harvard Business Review journal contradicts the notion that developing a loyal customer base can increase steady revenues. The study shows that loyal customers can sometimes be costly to firms, and while there is a correlation between loyal customers and profits, this correlation is not as strong as many researchers claim (Reinartz and Kumar, 2002). In a similar article, Gerstner and Libai (2006) suggest that unsatisfied customers may maintain a relationship with a firm due to high switching costs.

The substantial growth in the use of technology is not unique to the business sector. According to a 2011 Pew Research study (Taylor, et. al.), nearly $90 \%$ of all four-year public colleges and universities offer online classes, compared to $60 \%$ of four-year private schools. Online enrollments continue to grow at a rate of $33 \%$ annually in what is a $\$ 52$ billion industry (Ozkan, Koseler, and Baykal, 2009; Rydezewski, Eastman, and Bocchi, 2010). From the provider to the user, both universities and students cite advantages in cost savings, accessibility, and flexibility as primary drivers for increased use (Cargo, 2000; Asfour and Bryant, 2011; Ozkan, Koseler, and Baykal, 2009).

In addition to the benefits of online education, proponents consistently cite high levels of student satisfaction and academic rigor when compared to traditional classes (Cargo, 2000; Moskal, et al., 2006; Asfour \& Bryant, 2009, 2011; Ozkan, Koseler, and Baykal, 2009). Students who take online courses cited the flexibility of coursework to better balance work and family, self-paced learning, savings in driving time, and positive communication with instructors as reasons for satisfaction with their online education experience. Moskal et. al. (2006) summarized students' satisfaction with online learning by finding that $83 \%$ of students who took online courses expressed their satisfaction and cited "convenience and flexibility" as primary reasons for their satisfaction.

In contrast, Nowell's research (2011) demonstrates no difference in student satisfaction for online and traditional courses. In agreement with this work, Rydezewski, Eastman, and Bocchi (2010) also show no difference in the quality of education in online MBA programs and traditional MBA programs. In contrast, Taylor et al. (2007) notes a significant dissatisfaction by finding "one-in-five college graduates (22\%) say an online course offers an equal educational value, while $68 \%$ say it does not." In addition to this finding, Moskal et al. (2006) found that only $39 \%$ of online students felt their courses were equivalent to the traditional classroom setting. As the literature shows, discrepancies remain relative to the satisfaction levels of online vs. traditional students. However, the significance of satisfaction to consumers remains an area of needed research and importance to business and higher education. 


\section{SATISFACTION, TRUST, AND LOYALTY}

Satisfaction can be measured in many dimensions and is the single most researched theme of marketing research with varied measurement methods. The research literature is divided as to how satisfaction must be defined and measured. Oliver (1979) states that satisfaction refers to a state given after an experience based on the customer's evaluation of the attributes and performance of a specific transaction. However, the work of Floh and Treiblmaier (2006) demonstrate the work of several authors who find that satisfaction must be defined in a broader and more cumulative interpretation of one's exchanges and encounters with a firm or setting after their occurrence. In measuring satisfaction, instruments that measure single and multiple aspects both exist as the norm in this field of research (Siritongthaworn and Krairit, 2006). However, trust is one of the central factors in measuring satisfaction. Trust is an antecedent to customer satisfaction and is critical to loyalty, regardless of the context (Seargeant and Woodliffe, 2007). The significance of this finding is especially relevant for online retail providers as well as educational providers. Hitt and Chen's (2002) work demonstrated that consumers tend to search fewer sites by as much as $70 \%$ as they become more experienced with online shopping. This finding has important significance as it relates to the online customer's satisfaction and the firm's profitability. Within education, student satisfaction with the undergraduate experience is seen as the most central predictor of an alumnus' willingness to make a contribution to their alma mater (Sun, Hoffman, and Grady, 2007; Clotfelter, 2001, 2002; Drew-Branch, 2008).

The significance of customer loyalty to firms stands as a crucial element for businesses to build a base for the expansion of revenues as well as brand recognition. However, one of the most important factors for customer loyalty is profitability, as customer loyalty has been established to positively correlate with profitability (Huang, Cheng, and Farn, 2007; Helgesen, 2006). In fact, customer loyalty and profitability are fundamental to surviving and flourishing firms, most notably online firms (Christodoulides and Michaelidou, 2011). As demonstrated through the success of Amazon.com's loyal customer base and Floh and Treblmeier's 2006 work on e-banking customers, as well as Huang, Cheng, and Farn's research (2007), there is a strong correlation between loyal customers and profitability. The online user experience and were key to understanding customer satisfaction from these studies.

While the business literature demonstrates the importance of customer satisfaction, findings in higher education also note the importance of satisfaction at the undergraduate level in relation to loyalty and overall profitability by contributing to a university's annual fund and annual budget. For purposes of this study, the undergraduate experience is the sum of all educational experiences that occurred while taking courses at the undergraduate level. Higher education literature shows that an alum's likelihood to give back to their alma mater after graduation correlates to their undergraduate experience (Sun, Hoffman, and Grady, 2007; Clotfelter, 2001, 2002; Drew-Branch, 2008). For example, in Clotfelter's studies, analysis was performed on the Colleges and Beyond Study, a survey of students from 34 different colleges and universities. The study concluded that a student's undergraduate experience and their capacity to give are predictors of an alumnus' propensity to give back to their alma mater. Similarly, the work of Sun, Hoffman, and Grady (2007) used two years of data from a Midwest public university to find a correlation between alumni giving and the undergraduate student experience, including on campus involvement. Drew-Branch also affirmed the previous two studies in her 2008 dissertation on alumni from California University of Pennsylvania, finding a statistically significant correlation with a student's undergraduate experience and willingness to give back to the university.

In recent years, colleges and universities have seen reduced funding from traditional government sources as well as decreases in earnings in endowments after the fallout of the U.S. and global financial markets. As a result, colleges and universities seek to subsidize reduced revenues in traditionally reliable areas by calling upon alumni to give. One study shows that improving donor satisfaction can result in the improvement of an institution's return on investment by as much as $100 \%$ to $150 \%$ (Sargeant and Woodliffe, 2007). The significance of these studies holds importance for colleges and universities because alumni serve as a prime constituency for fundraising opportunities. Donations can be considered an indicator of the institution's educational performance; alumni who donate recognize the role the institution played in their education (Sun, Hoffman, and Grady, 2007). As one researcher bluntly stated, alumni involvement is most commonly recognized through financial contributions (Gardner, Van Der Veer, 1998). For this reason, the U.S. News and World Reports includes alumni donations as one of their 16 "key measure(s) of quality" when ranking U.S. colleges and universities (U.S. News, 2011). It should be noted that the U.S. News and World Reports model faces considerable criticism from academicians for its tendencies to encourage schools to 
stretch the truth by improving their scores and making education processes merely quantifiable (Zell, 2001; Thompson, 2000). With these criticisms in mind, the financial contribution of alumni stands as the overwhelming representation of an alumnus' stamp of satisfaction for their undergraduate experience.

\section{FACTORS OF SATISFACTION AND LOYALTY IN HIGHER EDUCATION}

While the literature on the significance of customer loyalty varies, the overall thesis of studies and articles reflect that businesses do better when they retain their customers. The same can be said of higher education, which focuses a great deal of energy in student retention and satisfaction. Student satisfaction is a key component to student retention, which is an important aspect for universities' cash flows. One of the most popular and highly cited approaches to improving student satisfaction at the undergraduate level is based on the theory of student involvement. This theory, derived from the work of higher education scholar and researcher Alexander Astin, states that there is a direct and positive correlation to a student's undergraduate experience and the "amount of physical and psychological energy that the student devotes to the academic experience" (Astin, 1985). Two of the key areas critical to the undergraduate experience and satisfaction are where they live and involvement with other students.

In his book Achieving Education Excellence, Astin claims that the single most encompassing factor, regardless of age, race, gender, or family background, was the student's residence. Similarly, the research of De Araujo and Murray (2010) shows that students living on campus are more likely to be involved in on campus activities. Clearly, the significance and importance of students living in proximity to the campus and activities of the campus are directly related to a student's satisfaction with their undergraduate experience. However, the literature from Cargo (2000), Asfour and Bryant (2011) and Ozkan, Koseler, and Baykal (2009) demonstrates that students have greatly benefited from online courses because these allow them to better balance work and family, among other factors. Yet, these findings stand in direct competition with the theory of student involvement.

The theory of student involvement assumes a direct correlation to a student's involvement on campus and satisfaction with their undergraduate experience, a finding other researchers discovered. Miller and Casebeer (1990) found that students who participated in activities offered by the university, such as honor societies, and athletic teams, and other extracurricular organizations, such as Greek societies, reported a stronger relationship with their alma mater than students who did not participate in activities. Similar findings were also reported in the work of Drew-Branch (2011). The research of Astin (1985) also found that students involved in fraternities, sororities, and intramurals dropped out of college at a lower rate than those who did not, indicating some degree of dedication to their undergraduate institution. To further validate the significance of student satisfaction and alumni giving, Lawley (2008) and Sun, Hoffman, and Grady (2007) found that students who were involved in on-campus organizations and activities were more likely to give to their undergraduate institutions than those who did not.

With such emphasis given on the student involvement theory, the opportunity for students to avoid coming to a physical campus certainly decreases the possibility for them to be more involved on campus, especially in campus organizations. The research of Astin (1993) finds that the distance of a student's campus engagement from their home directly relates to their satisfaction with the undergraduate experience. In addition to the work of Astin, other researchers such as Miller and Casebeer (1990) and Drew-Branch (2011) also supported this theory. In contrast, several studies have shown how the field of business has effectively utilized technology to give customers and employees more free time were found to have higher levels of satisfaction.

A significant and reoccurring factor influencing an alumnus' satisfaction with their undergraduate experience and willingness to give back to their alma mater depends on age. Numerous researchers have discovered a direct correlation to an alumnus' age and their willingness to give (Okunde and Berl, 1997; Sun, Hoffman, Grady, 2007; Lawley, 2008; Drew-Branch, 2011). In fact, the 2007 study by Sun, Hoffman, and Grady identifies several variables which serve as predictors for alumni donations, and find the most significant predictor of alumni donations to be age. Much of the literature on age and alumni giving is predicated upon the theory that the older an alum, the more income they are able to give back to their institution. The literature suggests that age is a predictor of alumni giving and as well as the student's satisfaction with their undergraduate experience. While studies have shown that students both young and old are somewhat skeptical of online education (Taylor et. al., 2007), the use of online offerings has been essential to the growth of higher education. This has been especially true among nontraditional 
adult students (Pusser et. al, 2007). This particular demographic needs more flexibility and convenience, because they are more established with greater commitments and responsibilities.

A final area that researchers recognize as having an impact on alumni giving relates to the undergraduate's field of study. Belfield and Benney (2000) display how graduates from specific fields such as medicine, business, and social sciences are more likely to give than undergraduates from other fields such as education. The work of Okunde and Berl (1997) also demonstrate that particular majors within business schools (finance, real estate and insurance) are more likely to give than other majors within the business school. Again, in these writings as well as the research of others, the theory behind predicting factors of alumni giving rests upon fields of study that produce graduates with higher incomes such as business, law, and medicine. Also, the literature shows that students who graduate from fields where the potential to make higher levels of income tend to give back to their institution (Belfield and Benney, 2000).

The fact that the number of online courses has doubled in the past ten years indicates a newfound area of interest for its use in higher education. Studies indicate that online courses provide students desired flexibility in their lives, which can serve as a moderating factor leading to satisfaction (Cargo, 2000; Moskal, et al., 2006; Asfour \& Bryant, 2009, 2011; Ozkan, Koseler, and Baykal, 2009). However, studies also demonstrate considerable contrasts to these findings, showing undergraduate students who were greatly dissatisfied with the quality of online education (Moskal et al., 2006; Taylor et al., 2011). The most significant research questioning the ability of online education to increase satisfaction at the undergraduate level includes the "traditional" notions of student engagement and satisfaction, grounded in Astin's theory of student involvement. However, the research in business and in education both understand that customers (albeit client or student) give to their business and donate to those organizations with which they are most satisfied. To date, there has been no single comprehensive study performed to examine the relationship of online course use as a predictive variable of alumni giving. The fundamental question for this study seeks to determine to what extent undergraduate students and online course use indicate satisfaction as expressed through alumni giving. As previously shown, alumni giving depends primarily upon the significance of the undergraduate student experience.

\section{RESEARCH MODEL CONCEPTUALIZATION}

A study by Sinclaire (2010) demonstrates the significant positive correlations between job satisfaction and student satisfaction as they relate to online environments. Satisfaction in business and education settings rests on interactions, communication, and the systems used to advance both of these functions. Sinclaire notes, "The determinants of student satisfaction with online learning are strikingly similar to the determinants of job satisfaction" (p. 8). The author suggests that managerial actions that improve satisfaction in work environments may prove effective in improving student satisfaction and achievement. This study extends the research of Sinclaire (2010) through an examination of the effects of online course use in higher education and its impact on a student's undergraduate experience, as expressed by alumni giving.

The overall purpose of this study examines the relationship of online course use to the undergraduate student experience as measured through alumni giving. For the purposes of this study, the following five factors found within the university were measured against alumni giving: residence during senior year, student organization involvement, age, major, and number of online classes taken during the undergraduate experience. Two of the primary factors contributing toward a student's undergraduate experience include their involvement in a campussupported organization, which, for the purposes of this study, does include Greek organizations as well as oncampus organizations and the second factor stands as a student's residence (on or off campus). Historically these two components of the student experience are central to an alumnus appreciation of their alma mater (Astin, 1984).

However, the development literature also suggests that age can have a significant impact on an undergraduate's experience (Okunde and Berl, 1997; Sun, Hoffman, Grady, 2007; Lawley, 2008; Drew-Branch, 2011). This theory is based on an alum's ability to give more money as more is available later in life. In addition, undergraduate majors have shown to serve as a significant predictor of an alumni's propensity to give back to their institution (Belfield and Benney, 2000; Okunde and Berl, 1997). As with age, Belfield and Benney (2000) and Okunde and Berl (1997) state that alumni from in fields with greater earning potential are more likely to give back. 


\section{HYPOTHESES}

This study examines the number of online courses taken by a student during their undergraduate experience as a predictor for alumni giving. This serves as the primary hypothesis of this study, while the previously mentioned variables of residence, student organization involvement, age, and undergraduate field of study were also measured against alumni giving to further test these commonly held beliefs with the advancement of technology. Two of the predictors of alumni giving come from the student development literature, and two come from advancement literature. Hypothesis 1 examined the number of online courses taken by a student during their undergraduate experience as a predictor for alumni giving. Hypotheses 2-5 represent variables within business and education literature that have been recognized as standard predictors of alumni giving.

$\mathbf{H}_{1}$ : $\quad$ Undergraduate students taking one or more online courses will affect alumni donations.

$\mathbf{H}_{2}$ : $\quad$ Undergraduate students who lived on campus during their senior year positively affect alumni donations.

$\mathbf{H}_{3}$ : Undergraduate students in at least one student organizations on campus positively affect alumni donations.

$\mathbf{H}_{4}$ : Student age positively affects alumni donations.

$\mathbf{H}_{5}$ : Undergraduate students majoring in business, healthcare, and pre-professional programs positively affect alumni donations.

\section{METHODOLOGY}

In January 2012, the researcher requested data from a medium, private-non-profit liberal arts university in the United States based on classifications established by the Carnegie Foundation. The university's Institutional Review Board approved the release of data for all undergraduate students, including non-traditional undergraduate students from 2004-2011. Including non-traditional undergraduate students means accepting all programs at the Associate and Bachelor's level, designed for both traditional and non-traditional models. The researcher felt this range of ages and degrees provides a wide range for ages, majors, and additional factors that may influence the predictive model in this study.

The overall sample includes 9,481 students. Student names and ID numbers have been withheld, and the following areas are included: gender, city, state, county, whether they lived on campus during senior year (yes or no), campus organization membership, did they take online courses (yes or no), the number of online courses taken, number of online courses completed, did they graduate (yes or no), field of study, did they donate (yes or no), and the amount of donation. For this study, a student's place of residence was determined by where they lived during the senior year. This was chosen because most institutions require students to live on campus during the first and sometimes second year(s). Selecting students who chose to live on campus during their final year most likely represents a student who has lived on campus from the inception of the college experience. Of the 9,481 students sampled, the ratio of males to females is $41: 59$ per 100, and the average age for undergraduate students at the point of graduation is 30 with a median age of 26 . Of the sample who provided their birthday, $48 \%$ were between the age of $17-25,20 \%$ between $26-30,14 \%$ between $31-40,16 \%$ between $41-59$, and $2 \%$ between $60-89$ years of age. The data indicates that $32 \%$ of the students included in this study lived on campus during their senior year compared to $58 \%$ living off campus, while 34\% were involved in a campus sponsored organization, and slightly fewer (30\%) had taken one or more online courses during their undergraduate studies. Within the sample, eleven different majors were identified as undergraduate majors. Of those eleven, five were identified as professional programs.

The focus of this study examines the correlation of online course participation with alumni donations. The analysis utilizes logistic regression because the dependent variable (alumni donation) is based on a binary variable (yes or no), not an amount. While online courses have been in use for the last decade, the data sample used for this study analyzed students over the past seven years. As previously mentioned, one of the primary determinants of an alumnus' propensity to give back to their alma mater focuses on earning potential, which can be related to the number of years this potential can be realized after graduation. Thus, because of the relationship between earning 
potential and the time lapse after graduation as well as the data dating back only seven years, the study utilizes a binary variable for analysis.

The original sample included a significant number of data points representing students who had not completed their degree. In an initial logistic regression, the presence of students in the data sample who did not complete their degree represented a standard coefficient of almost four times stronger than any other standard coefficient represented. The presence of these students also complicated the ability to define an alumnus if they had indeed not graduated from the university providing data. Thus, the sample was reduced to include only students who received a degree from the university, helping to better normalize the data. This step reduced the number of data points from 9,481 to 3,450 . After this was performed, a testing of outliers was performed by analyzing the standardized residuals, based on an absolute value of 3.0, reducing the number of data points from 3,450 to 3,381 to be used for final analysis.

\section{DATA ANALYSIS}

After non-graduating alums and outliers were removed, a final data set was established. Of this data set, the average age rose two years to 32 , and $13 \%$ of this set gave back to their alma mater in the form of a donation. Students who were living on campus during their senior year were 1,456 or $45 \%$, and the number of students involved in a campus sponsored organization was 1,257 or $39 \%$. The average number of online courses taken during the undergraduate experience was 1 , with the maximum number of online classes stood at 13 . Over half the students of this sample did not take a single online course during their undergraduate experience. By use of a histogram, the chart overwhelmingly demonstrated that hardly any student took more than 4 online courses during the undergraduate experience. The presence of multicollinearity was tested and did not find a VIF $<2.0$ and tolerance greater than 0.1 (O'Brien, 2007). After testing for multicollinearity, a regression analysis was performed.

The final probability formula for as stated through the regression analysis included age, the number of online courses completed, whether or not they lived on campus during Senior year, whether they were a member of a campus organization, as well as eleven different majors. The data for this final sample includes significant $r$-square values of .207 (McFadden), .15 (Cox and Snell), and .276 (Nagelkerke), indicating that the logistic regression model supplies a good proportion of the variability of alumni donations that may be accounted for by the other independent variables (See Table 1.1). These R-square values demonstrate that the model fits well for predicting alumni donations from online course users. The Relative Operating Curve (ROC) or relative accuracy of the model demonstrated an average of $78 \%$ (or area under the curve), which is higher than the donor predictability model proposed by Okunde and Berl (1997).

Table 1.1: R-Square Values

\begin{tabular}{|l|c|c|}
\hline \multicolumn{1}{|c|}{ Statistic } & Independent & Full \\
\hline Observations & 3271 & 3271 \\
\hline $\mathbf{R}^{2}$ (McFadden) & 0 & $\mathbf{0 . 2 0 7}$ \\
\hline $\mathbf{R}^{2}$ (Cox and Snell) & 0 & $\mathbf{0 . 1 5}$ \\
\hline $\mathbf{R}^{2}$ (Nagelkerke) & 0 & $\mathbf{0 . 2 7 6}$ \\
\hline
\end{tabular}

In addition to significant R-square values and a substantial area under the ROC curve, the study also returned significant p-values. The overall correlation of the tested measures of age, living on campus, campus organization member, choice of major, and the number of online courses completed, returned results significant at the .001 level or higher for age, on-campus living, and on-campus organizational involvement. This demonstrates the significance of these variables as predictors for alumni donations. The p-value of the number of online courses completed returned at the .002 level, also of statistical significance. The only variable which did not return a statistically significant correlation with alumni giving was undergraduate majors in business, healthcare, or preprofessional programs.

After review of the R-square values, area under the ROC, and p-values, the direction of correlations were also considered. Age, whether they lived on campus, and whether they were involved in a campus organization are all significant and positively correlated with alumni giving. In contrast, the number of online courses a student 
completed had a negative correlation with alumni giving. None of the majors strongly correlated with alumni giving. Table 1.2 summarizes the stated hypothesis and their effects.

Table 1.2: Results of Hypotheses

\begin{tabular}{|c|c|c|}
\hline Hypothesis & Reject/ Accept & P-Value \\
\hline $\mathrm{H}_{1}$ : Undergraduate students taking one or more online courses will affect alumni donations. & Accept & .002 \\
\hline $\begin{array}{l}\mathrm{H}_{2} \text { : Undergraduate students who lived on campus during their senior year positively affect alumni } \\
\text { donations. }\end{array}$ & Accept & .0001 \\
\hline $\begin{array}{l}\mathrm{H}_{3} \text { : Undergraduate students involved in at least one student organizations on campus positively } \\
\text { affect alumni donations. }\end{array}$ & Accept & .0001 \\
\hline $\mathrm{H}_{4}:$ Student age positively affects alumni donations. & Accept & .001 \\
\hline $\begin{array}{l}\mathrm{H}_{5} \text { : Undergraduate students majoring in business, healthcare, and pre-professional programs } \\
\text { positively affect alumni donations. }\end{array}$ & Reject & .6 \\
\hline
\end{tabular}

$\mathrm{H}_{1}$ was accepted as it demonstrated that alumni donations negatively correlated to completed online courses at a statistically significant level. There are two possible interpretations for this result: The first interpretation states that Astin's theory of student involvement proves true, and the less interaction an undergraduate student has on campus will diminish their undergraduate experience, making them less likely to give back as an alumnus (Astin, 1985). The second interpretation draws from the business literature which posits that e-commerce experience is inherently related to the online experience itself, i.e. quality and speed of exchange, significantly saved user time, etc (Floh and Treblmeier, 2006; Huang, Cheng, and Farn, 2007). Further research is needed to make a more conclusive decision on this hypothesis.

Following $\mathrm{H}_{1}, \mathrm{H}_{2}-\mathrm{H}_{4}$ were accepted for validating the research literature which states that living on campus, campus organization involvement, and age of the student are all valid predictors of a student's propensity to become an alumni donor. These findings do indeed validate Astin's theory of student involvement as well as other findings in the educational research literature that link student satisfaction with involvement on campus.

The study rejected $\mathrm{H}_{5}$ which predicted that particular majors in higher earning fields would be more likely to become a donor. While this is a regularly cited factor in predicting a donor's propensity to give back to their alma mater, it did not stand at a statistically significant level. This is most likely related to one of the limitations of this study going back to seven years, which lessened an alumnus' ability to create greater earning power that would have been created with a more long-term study.

\section{LIMITATIONS OF STUDY AND FURTHER RESEARCH}

There were several limitations to this study. An inherent limitation in online donor research for undergraduates exists due to the time lag between graduation and creating significant earning potential for alumni. Because online courses have been in use largely over the past 10-15 years, many undergraduate have not yet been able to create discretionary income at a level they can give back to their institution. It is recommended that a longitudinal study follow up this study that follows students through graduate degrees as well as during a longer time period that sees them establish a higher earning power.

A second limitation of this study is the scope of the study which examined data from only one mediumsized private liberal arts university. The inclusion of additional universities of similar size would further validate (or invalidate) the findings of this study. The researcher recommends expanding the study to at least 2-5 other universities of similar size but greater diversity in program offerings, both online and in professional programs. In expanding the scope of the study, it is recommended to include other universities which have a more extensive online learning model. For the private university examined in this model, the overwhelming majority of the sample did not take online courses, and the highest use group on average took four classes. Thus, involving universities who have a broader online learning program would add significant credibility to the study.

Finally, a third limitation and area for future study would be integration of the findings of this study with the development of student feedback concerning their undergraduate experience. This could entail a survey-based study with the use of a Likert scale, or a qualitative study conducted with the use of interviews. One advantage of 
using a survey-based instrument could involve current students to measure intent to give as measured by results in later years. A qualitative study could further expound upon the quantitative findings. Such studies could significantly bolster the data supported by this paper.

\section{AUTHOR INFORMATION}

Dr. Andrew Tiger serves as Professor of Management at Union University. E-mail: atiger@uu.edu

Mr. Landon Preston serves as the Director of Donor Relations at Union University. E-mail: 1preston@uu.edu (Corresponding author)

\section{REFERENCES}

1. Ahmed Al-Asfour, and Bryant, C. (2011). Perceptions of Lakota Native American Students Taking Online Business Course at Oglala Lakota College (OLC). American Journal of Business Education, 4(10), 43-50. Retrieved from http://search.proquest.com/docview/900867434? accountid=14640

2. Araujo de, P., Murray, J. (2010). Channels for Improved Performance From Living On Campus. American Journal of Business Education, 3(12) 57-64.

3. Astin, A. (1985). Achieving Education Excellence. San Francisco: Jossey-Bass.

4. Astin, A. (1993). What Matters in College? Four Critical Years Revisited. San Francisco: Jossey-Bass.

5. Byrne, J. (2011). Which B-schools have the most satisfied alumni? Fortune Online Edition. Retrieved from: http://management.fortune.cnn.com/2011/05/31/which-b-schools-have-the-most-satisfied-alumni/

6. Cargo, R.A. (2000). Made for Each Other. Nonprofit Management Education, Online, Technology, and Libraries. Journal of Academic Librarianship, 26(1), 15.

7. Christodoulides, G., \& Michaelidou, N. (2011). Shopping Motives As Antecedents Of E-Satisfaction And E-Loyalty. Journal of Marketing Management, 27(1/2), 181-197.

8. Clotfelter, C.T. (2001). Who are the Alumni Donors? Giving by Two Generations from Selective Colleges. Nonprofit Management and Leadership, 12(2), 119.

9. Clotfelter, C.T. (2003). Alumni Giving to Elite Private Colleges and Universities. Economics of Education Review, 22(2), 109.

10. Colfax, R., Santos, A., \& Diego, J. (2008). Virtual Leadership: A Green Possibility in Critical Times but Can it Really Work? Journal of International Business Research, 8(2), 133-141.

11. Drew-Branch, V. (2011). Student Engagement, Alumni Satisfaction, And Alumni Donations at a Public Four Year Institution: An Analysis of how the Undergraduate Experience Influences Alumni Donations. West Virginia University. ProQuest Dissertations and Theses, 68. Retrieved from: http://search.proquest.com/docview/ 898950350? accountid=14640

12. Dubelaar, C., A. S., \& Savic, V. (2005). Benefits, impediments and critical success factors in B2C Ebusiness adoption. Technovation, 25(11), 1251-1262. Retrieved from: http://search.proquest.com/docview/195902459?accountid=14640

13. Floh, A \& Treiblmaier, H. (2006). What Keeps The E-Banking Customer Loyal? A Multigroup Analysis of the Moderating Role of Consumer Characteristics on E-Loyalty in the Financial Service Industry. Journal Of Electronic Commerce Research, 7(2), 97-109.

14. Flossi, A., Fraccastoro, K., \& Moss, G. (2010). Cross-Course Projects: Teaching Students on Changing Business Communication Methods. American Journal of Business Education, 3(1) 65-70.

15. Gardner, J. \& Van Der Veer, G. (1998). The Senior Year Experience. San Francisco: Jossey-Bass.

16. Gerstner, E. \& Libai, B. (2006). Why does Poor Service Prevail? Marketing Science, 25(6), 601-603.

17. Helgesen, Ø. (2006). Are Loyal Customers Profitable? Customer (Action) Loyalty and Customer Profitability at the Individual Level. Journal of Marketing Management, 22 (3/4), 245-266.

18. Hitt, L. \& Chen, P. (2002). Measuring Switching Costs and the Determinants of Customer Retention in Internet-Enabled Businesses: A Study of the Online Brokerage Industry. Information Systems Research, 13(3) 255-274.

19. Huang, L., Cheng, T., \& Farn, C. (2007). The Mediating Effect of Customer Loyalty Towards EBrokerages: An Enhanced Investment Model. Total Quality Management \& Business Excellence, 18(7), 751-770. 
20. Jones, R., R., Oyung, \& Pace, L. (2005). Working Virtually: Challenges of Virtual Teams. Hershey, PA: Idea Publishing.

21. Lawley, C., McInerney, W., Hirth, M., Robinson, T., \& Samarapungavan, A. (2008). Factors That Affect Alumni Loyalty at a Public University. Purdue University.

22. Miller, M. T. \& Casebeer, A. L. (1990). Donor characteristics of college of education alumni: Examining undergraduate involvement. Carbondale, Illinois: Southern Illinois University.

23. Mozkal, P., Dziuban, C., Upchurch, R., Hartman, J., \& Truman, B. (2006). Assessing Online Learning: What One University Learned about Student Success, Persistence, and Satisfaction. Peer Review, 8(4), 2629.

24. Nowell, G. (2011). Student Course Evaluations in Traditional and Blended Courses: A Case Study. American Journal of Business Education, 4(1) 13-18.

25. Nydegger, R. \& Nydegger, L. (2010) Challenges in Managing Virtual Teams, Journal of Business \& Economics Research. 8(3) 69-83.

26. O'Brien, R. M. (2007). A Caution Regarding Rules Of Thumb for Variance Inflation Factors. Quality and Quantity, 41(5), 673-690.

27. Oliver, R. (1979). An Interpretation of the Attitudinal and Behavioral Effects of Puffery. Journal of Consumer Affairs, 13 8-27.

28. Okunde, A. \& Berl, R. (1997). Determinants of Charitable Giving by Business School Alumni. Research in Higher Education, 38(2) 201-214.

29. Ozkan, S., Koseler, R., \& Baykal, N. (2009). Evaluating learning management systems. Transforming Government: People, Process and Policy, 3(2), 111-130.

30. Pusser, B., Breneman, D., Gansneder, B., Kohl, K., Levin, J., Milam, J., \& Turner, S. (2007). Returning to Learning. Lumina Foundation for Education: New Agenda Series. Retrieved from: http://www.luminafoundation.org/publications/ReturntolearningApril2007.pdf

31. Reinartz, W. \& Kumar, V. (2002). The Mismanagement of Customer Loyalty. Harvard Business Review, 80(7), 86-94.

32. Rydzewski, D., Eastman, J., \& Bocchi, J. (2010). Important Characteristics in an MBA Program: The Perceptions Of Online MBA Students. American Journal of Business Education 3(4) 33.

33. Sargeant, A., \& Woodliffe, L. (2007). Building Donor Loyalty: The Antecendents and Role of Commitment in the context of Charity Giving. Journal of Nonprofit \& Public Sector Marketing, 18(2), 47 68.

34. Siritongthaworn, S. \& Krairit, D. (2006). Satisfaction In E-Learning: The Context Of Supplementary Instruction. , 23(2) 76-91.

35. Shellenbarger, S. (2010) How Long Before you Hit the Breaking Point? Wall Street Journal-Eastern Edition [serial online]. Retrieved from: http://blogs.wsj.com/juggle/2010/06/03/office-workers-how-long-beforeyou-hit-the-breaking-point/

36. Sinclaire, J. (2011). Student satisfaction with online learning: Lessons from organizational behavior. Research in Higher Education Journal, 11 1-19.

37. Survey: E-commerce: Amazon's amazing ambition (2000). The Economist, 354(8159) Survey 24, 27. Retrieved from: http://search.proquest.com/docview/224057387?accountid=14640

38. Sun, X., Hoffman S., \& Grady, M. (2007). A Multivariate Causal Model of Alumni Giving Implications for Alumni Fundraisers. International Journal of Educational Advancement. 7(4), 307-333.

39. Taylor, P., Parker, K, Lenhard, A., \& Patten, E. (2011). The Digital Revolution and Higher Education: College Presidents, Public Differ on Value of Online Learning. Pew Social and Demographic Trends.

40. Thompson, N. (2000). Playing with numbers. The Washington Monthly, 32(9), 16-23. Retrieved from: http://search.proquest.com/docview/213673065? accountid=14640

41. U.S. News (2012). Undergraduate Ranking Methodology. Retrieved from: http://www.usnews.com/education/best-colleges/articles/2012/09/11/methodology-undergraduate-rankingcriteria-and-weights-2

42. Zell, D. (2001). The market-driven business school: Has the pendulum swung too far? Journal of Management Inquiry, 10(4) 324-338. Retrieved from: http://search.proquest.com/docview/203322808?accountid=14640 